veer 20 à 25 minuten heeft verlaten om drank en sigaretten te kopen, geen objectieve bevestiging kan worden gevonden. Het Hof heeft daaromtrent overwogen dat de verklaring van [medeverdachte 1] op dit punt wordt ontkracht noch bevestigd door peilgegevens.

Op grond van al wat hiervoor is weergegeven heeft het Hof, niet onbegrijpelijk en toereikend gemotiveerd, geoordeeld dat de verklaringen van [medeverdachte 1] dat de verdachte en de mededader [medeverdachte 3] verantwoordelijk zijn voor de dood van [slachtoffer], op belangrijke punten worden ondersteund door andere bewijsmiddelen en dat de verklaringen van de verdachte en de mededader [medeverdachte 3 ] in de overige bewijsmiddelen weerlegging vinden.

Het Hof heeft in deze zaak geen aanleiding gezien gebruik te maken van zijn bevoegdheid om [medeverdachte 1], die reeds in eerste aanleg in aanwezigheid van de verdediging door de Rechter-Commissaris is gehoord, ambtshalve in hoger beroep opnieuw te (doen) horen. Dat staat, ook in het licht van het recht op een eerlijk proces als bedoeld in art. $6 \mathrm{EVRM}$, niet in de weg aan het gebruik van de verklaringen van [medeverdachte 1] voor het bewijs door het Hof. Met de onder 5.3.1 weergegeven motivering van het Hof dat de tegenover de politie en de Rechter-Commissaris afgelegde verklaringen van [medeverdachte 1] steun vinden in andere bewijsmiddelen en de verklaringen van de verdachte en de mededader [medeverdachte 3] worden weerlegd in de overige bewijsmiddelen, heeft het Hof immers genoegzaam de redenen als bedoeld onder 5.2.1 opgegeven waarom het, anders dan de Rechtbank, de verklaringen van [medeverdachte 1] betrouwbaar acht.'

\section{NTS 2020/44}

\section{HR 28 januari 2020, 19/00127, ECLI:NL:HR:}

2020:122 lid 1 onder $2^{\circ} \mathrm{Sr}$, schuldig aan 'mensenhandel'. In deze zaak was de vraag aan de orde of dat oogmerk van uitbuiting aanwezig was. Dat in artikel $273 \mathrm{f}$ lid $1 \mathrm{Sr}$ voorkomende bestanddeel '(oogmerk van) uitbuiting' is in de wet niet gedefinieerd, anders dan door de opsomming in het tweede lid van een aantal vormen van uitbuiting, waaronder uitbuiting van een ander in de prostitutie. De vraag of - en zo ja, wanneer - sprake is van 'uitbuiting' in de zin van de onderhavige bepaling, is niet in algemene termen te beantwoorden, maar is sterk verweven met de omstandigheden van het geval. ${ }^{33}$ Het gaat erom dat het handelen van de verdachte - naar hij moet hebben beseft - als noodzakelijk (en dus door hem gewild) gevolg meebracht dat de ander door hem werd of zou kunnen worden uitgebuit. Het feit dat het slachtoffer minderjarig is en dat het gaat om prostitutie, maakt al snel dat sprake is van (een oogmerk van) uitbuiting. De verdachte is door het hof wegens 'mensenhandel' veroordeeld tot een gevangenisstraf voor de duur van zes maanden. Het middel klaagde dat het bewezen verklaarde 'oogmerk van uitbuiting' niet uit de door het hof gebezigde bewijsmiddelen kan volgen. Uit de bewijsvoering bleek dat de door het hof bewezen verklaarde gedragingen van de verdachte - bestaande uit het in zijn woning huisvesten van de aangeefster, die op dat moment de leeftijd van 18 jaar nog niet had bereikt plaatsvonden gedurende ongeveer anderhalve week. Voorts bleek uit die bewijsvoering dat de verdachte wist dat de aangeefster aldaar gedurende deze periode seksuele handelingen met derden tegen betaling verrichtte, dat hij wist dat zij minderjarig was en daar verbleef met haar vijftien jaar oudere vriend die de baas over haar speelde, en dat hij met de aangeefster en haar vriend afspraken heeft gemaakt over bijvoorbeeld de entree van de personen die naar zijn woning kwamen om daar tegen betaling seksuele handelingen te verrichten met de aangeefster. Verder heeft het hof vastgesteld dat de verdachte, ondanks zijn wetenschap omtrent dit een en ander, de minderjarige aangeefster gedurende deze periode is blijven huisvesten, waardoor zij in zijn woning klanten kon blijven ontvangen. Het onder meer op deze vaststellingen gebaseerde oordeel van het hof dat de verdachte het bewezen verklaarde 'huisvesten' heeft begaan met het 'oogmerk van uitbuiting' gaf volgens de Hoge Raad niet blijk van een onjuiste rechtsopvatting en was niet onbegrijpelijk.

\author{
Mensenhandel, art. $273 \mathrm{f} \mathrm{Sr}$. Gedurende ongeveer ander- \\ halve meek huisvesten van een zeventienjarige prostituee, \\ termijl hij mist dat zij klanten in zijn moning ontving en \\ zij minderjarig mas. Sprake van 'huisvesten' met het \\ oogmerk van uitbuiting a.b.i. art. 273f.1 Sr?
}

\section{Aantekening redactie}

Iemand die een ander huisvest met het oogmerk diegene uit te buiten, maakt zich ingevolge artikel $273 \mathrm{f} \mathrm{Sr}$ aanhef
33. Vgl. HR 27 oktober 2009, ECLI:NL:HR:2009:BI7099. 